\title{
BEFORE, DURING AND AFTER THE DANA OF SEPTEMBER 2019 IN THE REGION OF MURCIA (SPAIN), AS REPORTED IN THE WRITTEN PRESS
}

\author{
MARÍA ASUNCIÓN ROMERO-DÍAZ*, ALFREDO PÉREZ-MORALES
}

Dpt. of Geography, University of Murcia. Campus de La Merced, 30.001 Murcia, Spain.

\begin{abstract}
In September 2019 a DANA affected the Southeast of Spain with a special impact on the Segura Basin and the Region of Murcia. Heavy rainfall caused widespread flooding, very serious damage and generally affected the whole population. The main objective of this work was to analyse this episode through a follow-up of all the news published in two regional newspapers, La Verdad and La Opinión. To this end, a methodological proposal was made to classify the news according to: the typology of the subject, the relevance of the DANA in terms of frequency and how the news developed. A total of 816 news articles covering 52 days were studied and grouped into 26 subjects. The issues that aroused most interest, were those relating to the solidarity offered and aid provided to those affected, the effects on the Mar Menor (a nearby coastal lagoon); visits by politicians, personalities and their statements; solutions and mitigation measures; evacuations, rescues and displacements. The database analysed allowed us to organise the information into different aspects and in sequence: (i) prevention tasks and warnings prior to the materialisation of a risk situation; (ii) rescues, relief and assistance to persons, and (iii) response, rehabilitation and reconstruction.
\end{abstract}

\section{Antes, durante y después de la DANA de septiembre de 2019 en la región de Murcia (España), según se informó en la prensa escrita.}

RESUMEN. En el mes de septiembre de 2019 un DANA afectó el sureste español con un impacto especial en la cuenca del Segura y en la región de Murcia. Las fuertes lluvias provocaron inundaciones generalizadas, daños muy graves y afectaron en general a toda la población. El objetivo principal de este trabajo fue analizar este episodio a través de un seguimiento de todas las noticias publicadas en dos periódicos regionales, La Verdad y La Opinión. Para ello, se realizó una propuesta metodológica para clasificar las noticias según: la tipología del tema, la relevancia de la DANA en términos de frecuencia y cómo se desarrolló la noticia. Se estudiaron un total de 816 artículos informativos que abarcaron 52 días y se agruparon en 26 temas. Los temas que más interés despertaron fueron los relacionados con la solidaridad ofrecida y la ayuda brindada a los afectados, los efectos en el Mar Menor, las visitas de políticos, personalidades y sus declaraciones, las soluciones y medidas de mitigación, las evacuaciones, rescates y desplazamientos. La base de datos analizada permitió organizar la información en diferentes aspectos y en secuencia: (i) tareas de prevención y alertas previas a la materialización de una situación de riesgo; (ii) rescates, socorro y asistencia a las personas, y (iii) respuesta, rehabilitación y reconstrucción.

Key words: DANA, floods, written press, south-eastern Spain.

Palabras clave: DANA, inundaciones, prensa escrita, sureste de España.

Received: 1 July 2020

Accepted: 28 October 2020 
* Corresponding author: A. Romero Díaz, Dpt. of Geography, University of Murcia, Campus de La Merced, 30.001 Murcia, Spain. E-mail: arodi@um.es

\section{Introduction}

On September 12th and 13th, a "Cutt-of-low" or "DANA" (isolated high-altitude depression) struck the Southeast of Spain, affecting the Segura River Basin and the Region of Murcia very intensely. This work analyses the effects of the torrential rains, and the floods that caused significant damage to several areas of the Region of Murcia, based on the news published in the two most widely read local newspapers: La Verdad (founded in 1903) and La Opinión (founded in 1988). In 2019 the number of readers of La Verdad was estimated at 121,000 and those of La Opinión at 57,000.

Seventy-two hours before this weather event, the 'Meteoalerta' service of AEMET (State Meteorological Agency) began publishing warnings about the possible severity of this event, information that was relayed by the media. As the extreme weather unfurled, news on the same increased, especially in the immediate days after, although the effects were still being felt until long after. It was therefore considered appropriate to extend the observation period from the 10th of September (2 days before the DANA) to the 31 st of October (48 days later), when related news was already scarce or non-existent.

According to Olcina Cantos et al. (2004) "The daily press is a useful source for the study of extraordinary natural episodes, since newspapers provide information on the socio-territorial consequences of the same, situates the episode chronologically, identifies the effects in a region and provides graphic documents of the consequences". Newspapers have been widely used as a source of information similar studies in Spain, although following different approaches. Table 1 shows some of these studies showing greater thematic affinity with this research.

Table 1. Some of the publications related with weather and floods using information from the written press.

\begin{tabular}{|c|c|c|}
\hline Theme & Place/theme & Author \\
\hline Climate risks & $\begin{array}{l}\text { Catalonia } \\
\text { Western Mediterranean }\end{array}$ & $\begin{array}{l}\text { Llasat-Botija et al., } 2006 \\
\text { Llasat-Botija et al., } 2007\end{array}$ \\
\hline $\begin{array}{l}\text { Climate-weather } \\
\text { aspects }\end{array}$ & $\begin{array}{l}\text { Gran Canaria } \\
\text { Galicia } \\
\text { Basque Country } \\
\text { Catalonia } \\
\text { Iberian Peninsula } \\
\text { Palma de Mallorca } \\
\text { Extreme weather events } \\
\text { Weather and climate }\end{array}$ & $\begin{array}{l}\text { Mayer Suarez, } 1999 \\
\text { García Martínez and Martín Ezpeleta, } 2000 \\
\text { Hernández Valera et al., } 2003 \\
\text { Llasat et al., } 2009 \\
\text { Domínguez-Castro et al., } 2015 \\
\text { Torrens Calleja et al., } 2016 \\
\text { Lopera Pareja, } 2017 \\
\text { Olcina Cantos, } 2005\end{array}$ \\
\hline Floods & $\begin{array}{l}1978 \text { Flood in the Lower Segura } \\
\text { Las Palmas de Gran Canaria } \\
\text { Flooding in Alicante } \\
\text { Navarrese Cantabrian Valleys } \\
\text { Province of Cadiz } \\
\text { Rio Rojo, Manitoba, Canadá } \\
1948 \text { Flood in the Segura Basin } \\
\text { Historic floods in Texas } \\
\text { Floods in Spain 1995-2014 } \\
\text { Historic floods in France } \\
\text { Floods in Seville, 20th century } \\
\text { Flash floods in Great Britain } \\
\text { Flash floods in Great Britain } \\
\text { Floods as an educational resource } \\
\text { Flood chronology (14-20 century) } \\
\text { Mediterranean coast Spain (1960-2015) } \\
\text { Flooding in Vetania (Argentina) } \\
\text { Danube floods from1012 to the present }\end{array}$ & $\begin{array}{l}\text { Calvo García-Tornel et al., } 2001 \\
\text { Mayer Suarez, } 2002 \\
\text { Olcina Cantos et al., } 2004 \\
\text { Pejenaute Goñi, } 2008 \\
\text { Cuello Gijón, } 2010 \\
\text { Rashid, 2011 } \\
\text { Pérez Morales and Gil Guirado, } 2012 \\
\text { Melinda, 2015 } \\
\text { Gutiérrez Abril, } 2016 \\
\text { Lang et al., 2016 } \\
\text { León González-Mazón, } 2017 \\
\text { Archer and Fowler, } 2018 \\
\text { Archer et al., 2019 } \\
\text { Cuello Gijón, 2018 } \\
\text { Barriendos et al., } 2019 \\
\text { Gil Guirado et al., } 2019 \\
\text { Ortuño Cano et al., } 2019 \\
\text { Prohaska et al., } 2019\end{array}$ \\
\hline
\end{tabular}


In the above works, although the press seems to play a valuable role in identifying flood episodes, none of them tried to track a particular episode on day-to-day basis, as we have done in this work.

The main objective was to classify the news in the press related to a flood episode, specifically the one that took place in September 2019 in the Region of Murcia. Through frequency indicators related to the subject in the news and its chronological development, a sequence of environmental and socialrelated matters can be reconstructed that shows, among other things: the importance of the episode in its physical properties and derived socio-economic impacts; the attitudes and response strategies of the different institutions involved in risk management and, subsequently, the catastrophe itself; aspects that highlight the overall vulnerability of the affected system and ultimately increase the risk; the perception and type of measures proposed or adopted by local administrators of to alleviate the effects of the catastrophe. Finally, given the possible bias of the source of information, the news articles in two different newspapers dealing with the episode were compared in order to minimise this effect.

\subsection{Brief analysis of the DANA and the area of affection}

In order to have a more complete context of what happened with the DANA of September 2019 in the Region of Murcia, and thus be able to better assess its media impact, the following is a brief analysis of the atmospheric situation and the areas most affected by the intense rains.

The DANA took place as a result of the movement of a series of low pressures from the north to the south from the 11th (and subsequently inversely) combined with the entry of humidity from the Mediterranean on the 12th, which led to an explosive synoptic situation in the Spanish Mediterranean coast, mainly in the triangle formed from the south of the Region of Murcia, the eastern half of Albacete and the province of Valencia. This flow of humidity, together with the dominant instability, resulted in torrential rainfall which has been catalogued as historic in many places on the east of the Iberian Peninsula, and in particular in the Region of Murcia (Fig. 1), as well as a very notable sea storm, with waves which reached 4 metres. The most virulent part of the storm occurred from the early morning of the 12th to midday of the 13th. Several convective fronts moved from the north to the south, leaving torrential rain in their wake.

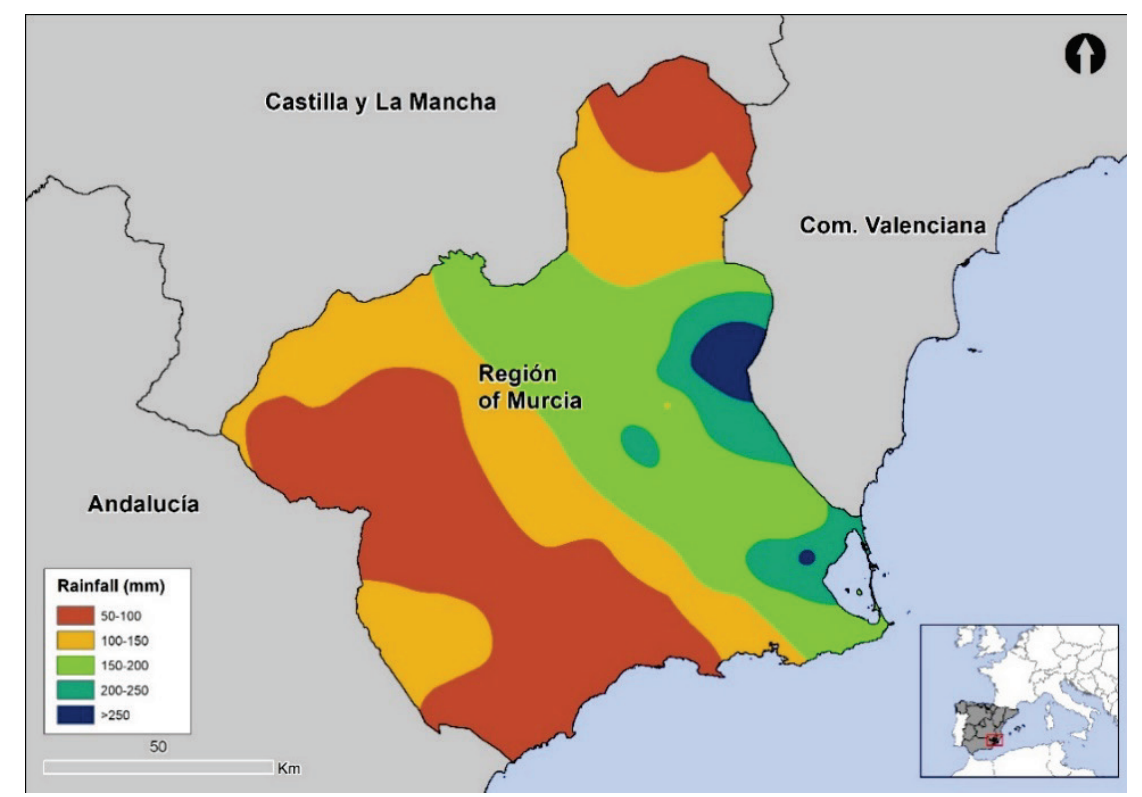

Figure 1. Precipitation recorded in the DANA episode in the Region of Murcia during September 12-13. Source: Own elaboration according to AEMET data. 
The episode left historical records, with rainfall falling in 2 days that equal or exceed the average annual rainfall in many parts of the region: Molina de Segura 374 litres, La Manga del Mar Menor 335 litres and San Javier 335 litres. In the Region of Murcia, the area most affected was the Vega Media del Segura and the Campo de Cartagena-Mar Menor, especially in the municipalities of Los Alcázares and San Javier (Fig. 2) on the slopes of the Mar Menor, with rainfall of $146 \mathrm{~mm}$ in one hour in La Manga del Mar Menor or $109 \mathrm{~mm}$ in San Javier. In addition, the concentration of rainfall in two events with a time lapse of just one day aggravated the situation.

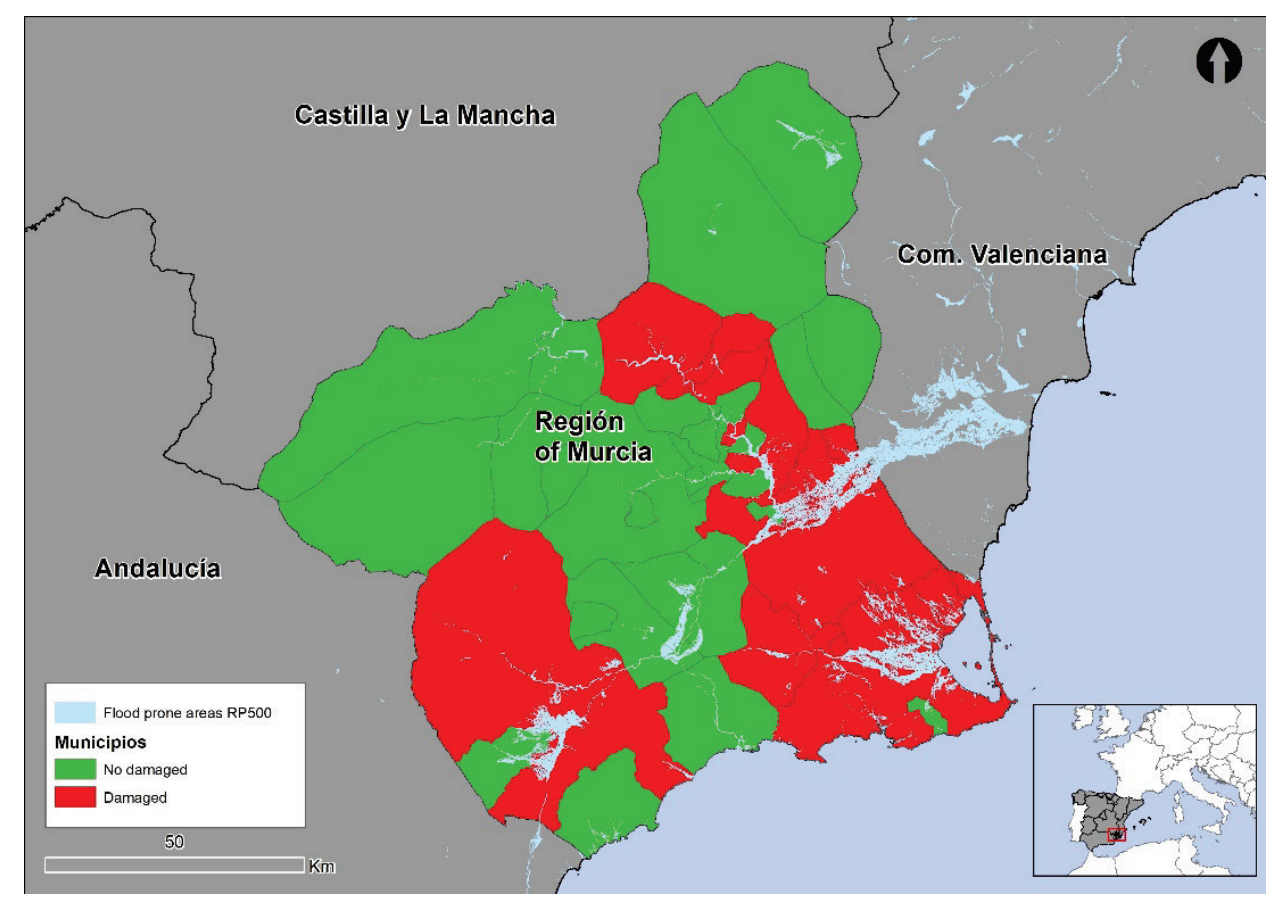

Figure 2. Municipalities affected by the DANA episode in the Region of Murcia. Source: Own elaboration according to data obtained from the press analysed.

The density of built up area on the coast, the occupation of watercourses (by housing, industry, crops, etc.), the increase in infrastructure, the elimination of soil conservation practices due to the installation of new "industrial" agriculture, and the low slope of the territory, meant that the DANA episode caused exceptional material and economic damage. It is worth noting, as can be seen in Figure 2 , that the areas with the greatest impact coincide with the areas of flooding for a return period of 500 years.

\section{Methods and sources}

Although the DANA also affected much of the Lower Segura in the province of Alicante, our study focused specifically on the province of Murcia, which is the range of distribution of the newspapers analysed.

The newspapers herein, not only related the daily events and numerous testimonies, but also provided chronicles, reports, opinion articles, editorials and images of what happened, from which it has been possible to obtain a very valuable set of data that present different points of view (descriptive, personal, technical, political, economic or scientific). We are aware of the advantages and disadvantage of press reports and occasionally sensationalist nature but, despite this, we consider it an important 
source of information, as long as that information is systematically and thoroughly processed and filtered.

The news collected by us, referring solely to the DANA episode and its consequences, differed depending on the day on it was published (before, during and after the event) and some items dealt with various aspects at the same time. The news items were grouped into 26 topics, including an "other" section, which included news that did not fit into our selected categories, which are described below:

1. Warnings and prevention

2. Cancellation of activities

3. Resumption of activities

4. Climate-weather aspects

5. Hydrological aspects

6. State of riverbeds, banks and beaches

7. Flooded areas and places

8. Management of reservoirs

9. Evacuations, rescues and displacements

10. Harmful effects on the population

11. Damage to property

12. Damage to infrastructure

13. Damage to agriculture, livestock and fisheries

14. Damage to industry and other property

15. Effects on the Mar Menor Lagoon

16. Solidarity with and aid provided to those affected

17. Emergency management

18. Damage and loss assessment

19. Declaration of a disaster area

20. Responsibilities

21. Compensation and payments

22. Visits by politicians and personalities, and their statements

23. Repairs and cleaning up

24. Causes of flooding

25. Solutions and measures to be taken

26. Other.

Overall, a total of 816 news articles were analysed, of which 467 were taken from the newspaper La Verdad and 349 from La Opinión. These numbers include opinion articles, jokes and cartoons and similar (Table 2).

Table 2. News analysed and extracted from the two regional newspapers.

\begin{tabular}{|c|c|c|c|}
\hline Type of news & La Verdad & La Opinión & TOTAL \\
\hline Varied & 435 & 333 & 768 \\
\hline Opinion piece & 18 & 13 & 31 \\
\hline Joke/cartoon & 14 & 3 & 17 \\
\hline TOTAL & 467 & 349 & 816 \\
\hline
\end{tabular}




\section{Results}

\subsection{Number of news items per day}

The number of articles related with the DANA varied as time progressed (Fig. 3). The highest number of news articles appeared between the 13th and 17th of September, since the heaviest rainfall was recorded on the 12nd and 13th of the same month. From the 18th of September onwards, the frequency of related news gradually diminished until about the 26th. From that time until the 10th of October, the average number of related articles per newspaper was five, dropping to two or three until the 26th of October, almost disappearing a few days later.

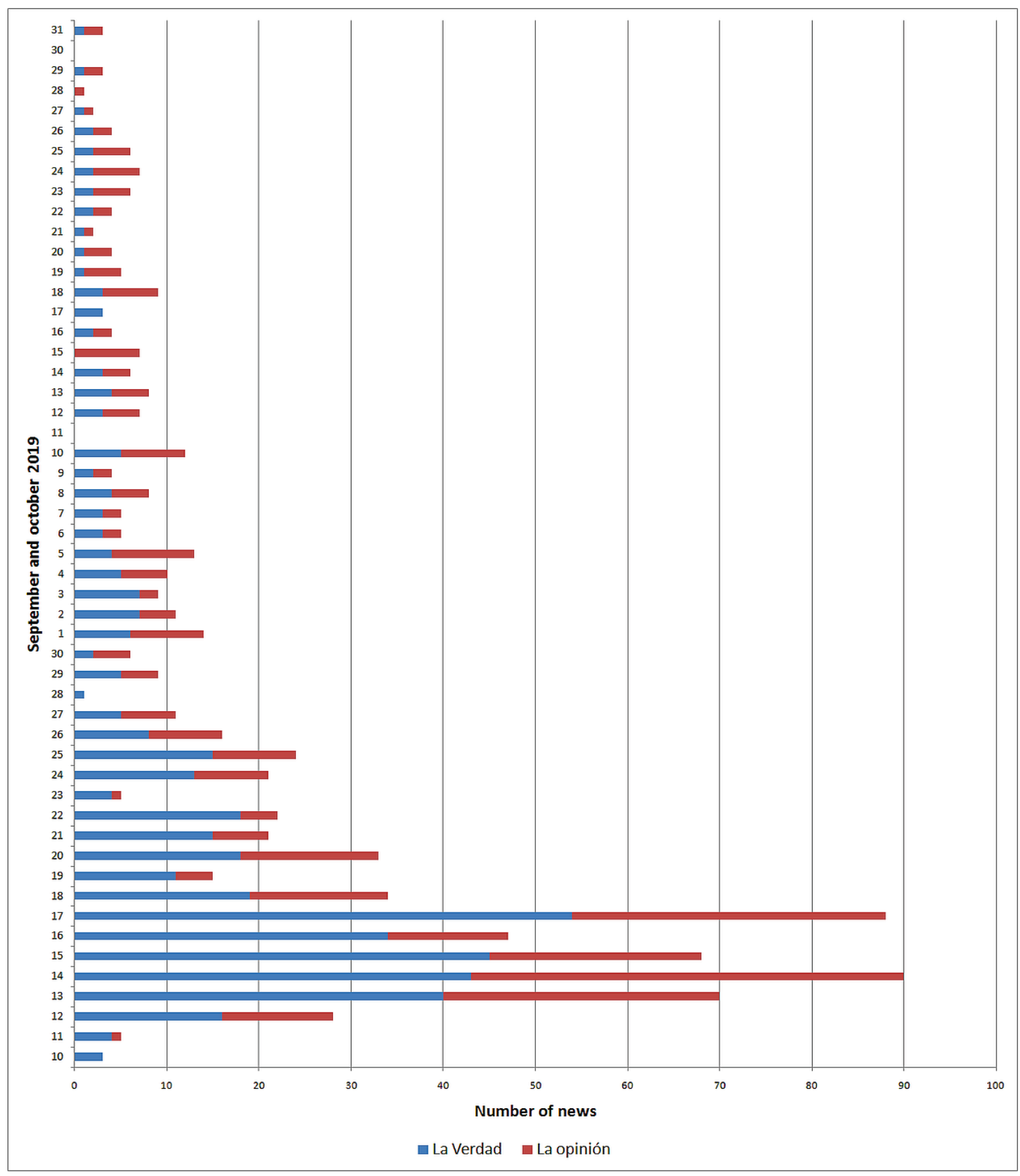

Figure 3. Number of daily news items published on the DANA in the two newspapers analysed between September 10th and October 31st. 
The number of articles in La Opinión was usually lower than in La Verdad, although on some days an almost equal number was published and even, at times, was greater in La Opinión. On the 13th of September both newspapers published an almost equal number of news articles, but La Verdad published more DANA-related news in September, while the memory of the episode was more evident in La Opinión in October.

\subsection{Thematic analysis of the news}

The number of news items differed depending on the subject and the newspaper (Fig. 4). Overall, the issues that were most addressed were solidarity of people and the aid provided to those affected (Topic 16), the effects on the Mar Menor Lagoon (Topic 15), followed by visits by politicians, personalities and their declarations (topic 22), solutions and measures (topic 25), and evacuations, rescues and displacements (topic 9). As for media differentiation, La Verdad focused more on solidarity, visits by politicians and infrastructure damage; while La Opinión did so on the effects of the DANA on the Mar Menor. There were little differences between the two newspapers in the extent to which they treated evacuations and rescues, damage assessment or solutions and measures alike.

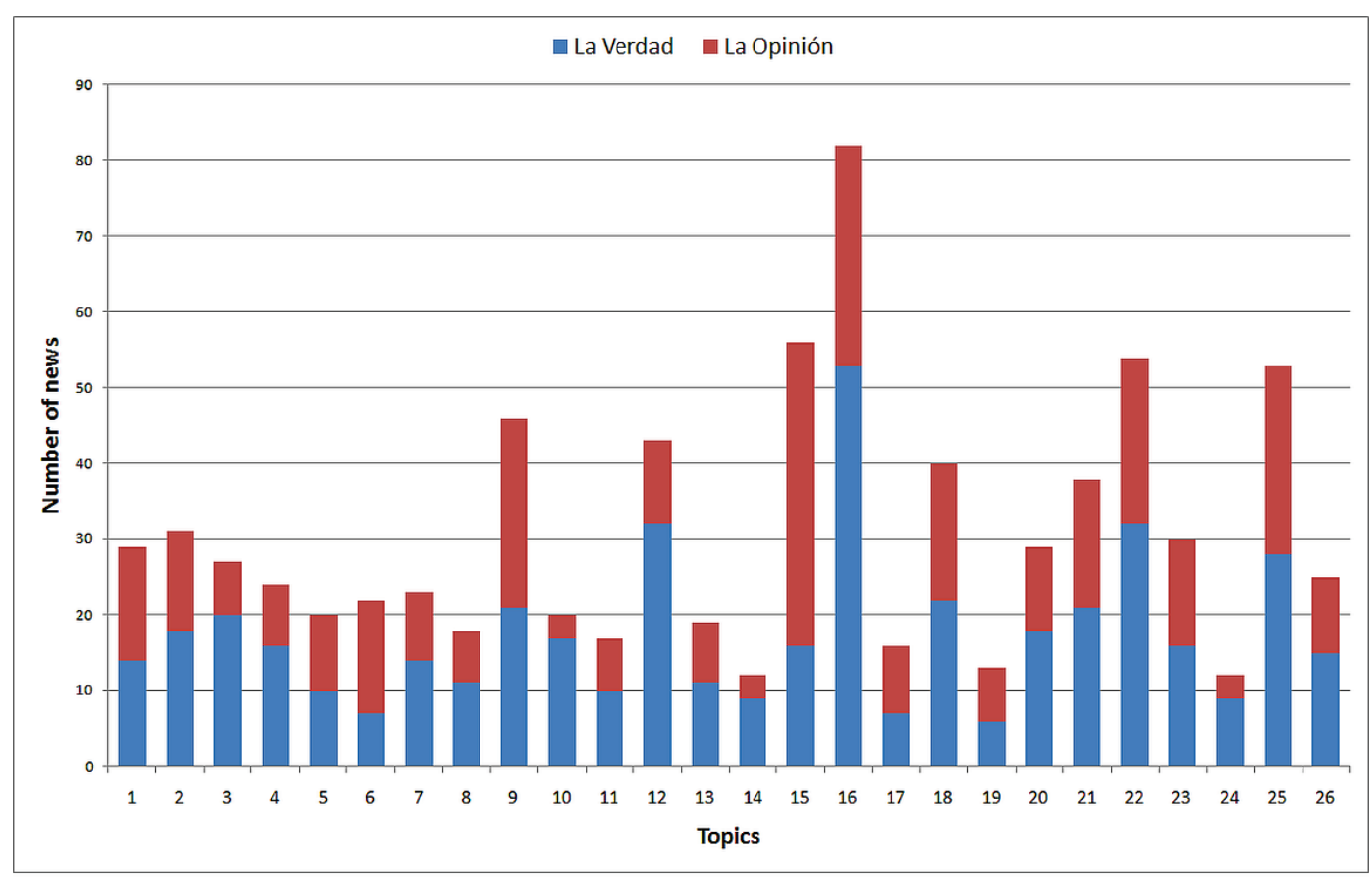

Figure 4. Number of news items by topic in the two newspapers analysed. See the methods and sources section for an explanation of the topic numbers.

The following is a summary of the news classified into topics:

1.- Warnings and prevention. The news items concerning warnings and prevention were obviously more numerous in the days leading up to the episode of DANA (10th, 11th and 12th), based on the warnings of AEMET. In both newspapers, the number of items was similar, with a similar content but different headlines. The news referred to the "maximum" alert level and that the DANA or cold drop would affect the whole region with rainfall of $200 \mathrm{l} / \mathrm{m}^{2}$. It should be noted that this was the first time that a red alert had been decreed for the whole region. Photographs appeared of teams urgently cleaning "ramblas" (dry river beds, intended to channel flood waters) in different parts of the region. People were advised not to use their cars, take extreme precautions and stockpile water, food and medicines. Sports facilities were refurbished to accommodate evacuees. On the 14th, reeds were still being removed against the clock 
from below the bridges of the city of Murcia to prevent the river from overflowing. On the 17th, after the extreme weather episode, prevention notices were issued by health authorities, urging to follow the advice of local council as regard the consumption of water and asking people to notify the authorities if they found animal carcasses.

2.- Suspension of activities. In anticipation of the red alert, a decree suspending activities was emitted on the 12th. Classes for all education levels were suspended and "EBAU" (university entrance examinations) were formally postponed. Fairs (common at that time of the year) were closed and all scheduled activities were suspended. In the municipality of Molina de Segura the local fair was postponed. In La Manga del Mar Menor a regatta was postponed, as well as other sporting events, and two cruise ships cancelled their stopovers in Cartagena. In Lorca, the Almenara shopping centre was closed and in different places of the province, industries and shops interrupted their activities. Because broken railway lines, all rail traffic connecting Murcia with Madrid, Barcelona and Cartagena was suspended. The law courts and other legal services of Murcia, Molina, San Javier and Mula were closed. Flooding also caused the closing of Corvera International Airport and the AP-7 motorway, while another 55 roads were cut. For several days afterwards, many schoolchildren (especially in Los Alcázares) could not return to class, the rail network was still awaiting repair and numerous roads were still not open to traffic. Eight days after the DANA the inhabitants of Los Alcázares still had no drinking water.

3.- Resumption of activities. News on the resumption of activities ran from the 15 th of September to the 20th of October, depending on the type of activity or infrastructure affected. Classes resumed in schools on different dates, depending on the degree of damage. The airport reopened and, in Los Arcos hospital (San Javier), flooded basements and operating theatres were disinfected. On September 20, rail traffic was restored between Murcia and Albacete, on October 10 with Alicante, on October 16 with Cartagena but not until October 20 with Águilas.

4.- Climate-weather aspects. The climate-weather data offered by the press varied. Data from official sources included radar images from AEMET on how the DANA was developing, and maps of the rainfall recorded in different locations in the region. Precipitation records were cited for the episode: $335 \mathrm{~mm} / \mathrm{m}^{2}$ in Molina de Segura, 264 in Torre Pacheco or 241 in Cieza; or $321 / \mathrm{m}^{2}$ fallen in 10 minutes in La Manga. Some of the headlines were very eloquent: "The Mediterranean hurricane", "There is no precedent for the water that has fallen", "The rain that has fallen equals to the rainfall of an entire year", "Floods break many records", "The most photographed and recorded [storm] in history", or "The worst flood of the last 70 years in the Region". The magnitude of this episode caused the Ministry of the Environment to call for declare a "climate emergency."

5.- Hydrological aspects. From a hydrological point of view, the press ran reports on overflowing "ramblas" carrying away everything in their path, such as those of Miranda in the area known as Campo de Cartagena, or those of Espinardo and Churra; and flooding of the Segura river in the municipalities of Cieza, Archena, Molina de Segura and in numerous villages of the municipality of Murcia. The amount of rain falling in the Segura basin amounted to $2800 \mathrm{hm}^{3}$ (more than twice the capacity of all its reservoirs) and it is estimated that the Segura discharged the equivalent of 20,500 Olympic swimming pools into the sea in four days $\left(51 \mathrm{hm}^{3}\right)$. Other noteworthy stories focused on the Santomera reservoir, which at one point held $20 \mathrm{hm}^{3}$, throwing into doubt its structural strength. On the 12th of September, a map of the 20 flood-sensitive areas in the region was published, but in light of the floods, and after verifying that this document was not true to reality, a new map rectifying the information was published on the 25 th of September. 
6.- State of riverbeds, banks and beaches. Many of the news reports were related to the state of the rivers and ramblas, criticizing the Segura Hydrographic Confederation (CHS in Spanish) for their negligence in cleaning water channels, or demanding their urgent cleaning, since this was cited as the main cause of the flooding. The images published of bridges blocked by reeds in the municipalities of Molina and Murcia were very illustrative. With regard to the beaches, in addition to their poor state, especially those surrounding the Mar Menor and in La Manga, three other facts were attributed to the DANA: (i) a reservoir built to retain mining waste in Portman overflowed (September 15); (ii) dead tuna were washed up on the beaches of La Manga because of offshore fish farms breaking (15 September); (iii) extremely hazardous mining waste entered the southern part of the Mar Menor through the ramblas (5 October); and (iv) an enormous amount of dead fish appeared in the municipality of San Pedro del Pinatar in the northern part of the lagoon (October 13 and successive days).

7.- Flooded areas and places. The most striking images correspond to September 13, highlighting the extensive areas and places flooded in the "huerta" (area dedicated to growing fruit and vegetables) in the municipalities of Molina del Segura, Archena, Alguazas and several villages near Murcia. On the 14th of September, images of Los Alcázares, known as ground zero, were published (Fig. 5).

On September 14th, a map was also published with the effects of the storm in various places in the region, especially in the Vega del Segura from Cieza to Alicante, suburbs of Murcia city bordering the Segura river, Santomera and Beniel, Lorca, Cartagena, and the municipalities bordering the Mar Menor: Fuente Álamo, Torre Pacheco, San Pedro del Pinatar, San Javier and Los Alcázares.

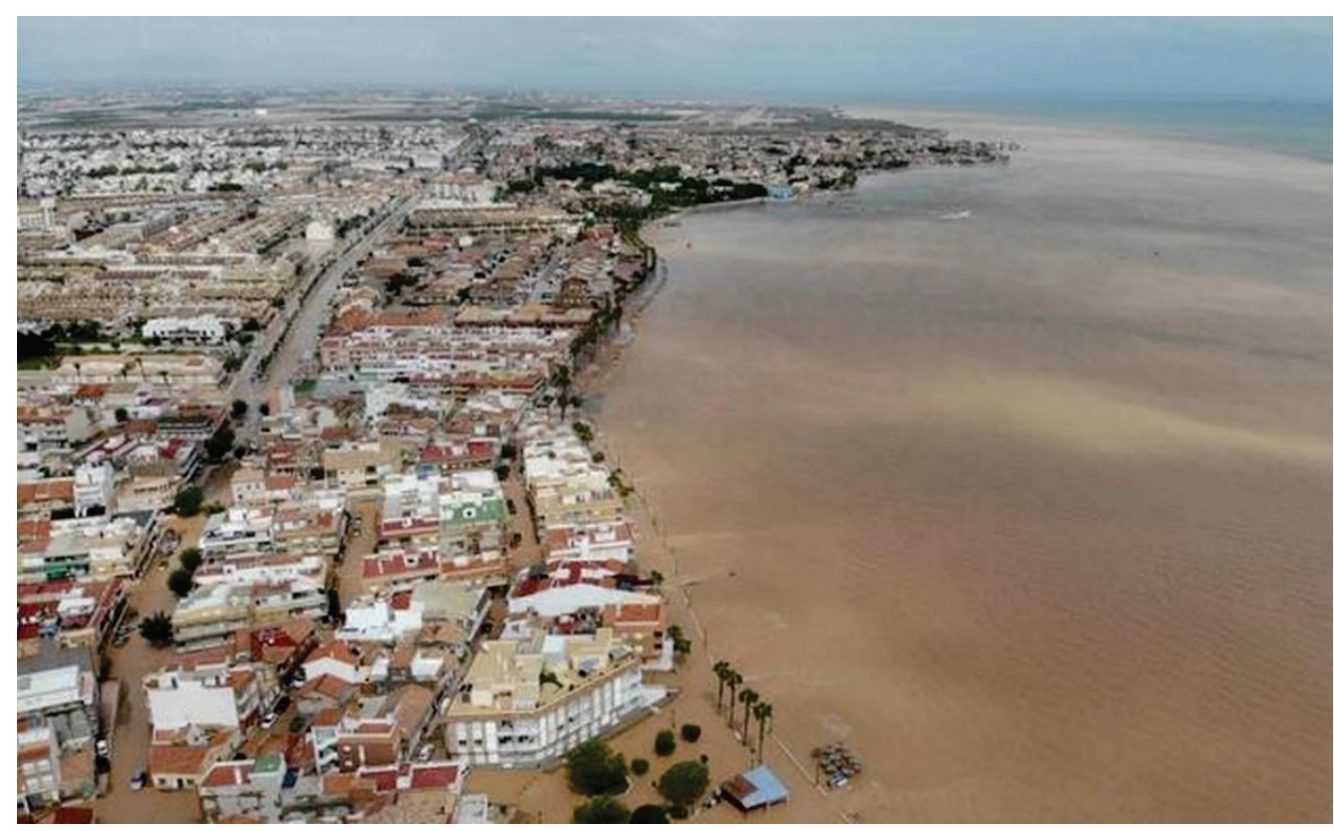

Figure 5. Aerial view of the effects of DANA on Los Alcázares and the Mar Menor. Source: La Verdad, 14th Sept 2019.

8.- Management of reservoirs. During the DANA, the reservoir in Santomera became the centre of attention, since this was the first time in its history that floodgates had to be opened and the water level lowered due to it reaching the limit of its capacity as a result of the waters collected from the ramblas and, in particular, the water coming from the ruptured canal of the Tagus-Segura transfer system. Other reservoirs that were closely watched were those at Camarillas (at the head of the Segura Basin), which also reached the limit of its capacity, or the one at Valdeinfierno (at the head of the Guadalentín river), which drains into the reservoir at Puentes (located downstream). 
In general, the role of these infrastructures and their management were called into question from different points of view. The CHS highly placed a high value on the expensive Anti-flood Plan (Ezcurra, 2007) and its president mentioned that the Santomera dam had saved lives. Others felt that the flood prevention works had led them to believe that the risk of flooding had been solved forever, which clearly was not the case. The CHS president also replied to people who claimed that there was a need for more reservoirs near the flooded villages and in the Vega Baja, mentioning that their construction was impossible in these places.

9.- Evacuations, rescues and displacements. Because of the danger of the Santomera reservoir overflowing or even breaking, several villages downstream of the reservoir had to be evacuated (e.g. El Siscar and La Matanza), although other towns had to be evacuated, too, including Cieza, Blanca, Molina de Segura, Alguazas, Abanilla, Fortuna, some districts of Murcia (El Raal, Alquerías, Zeneta and Santa Cruz), Los Alcázares, Torre Pacheco; as well as the campsites of the rambla de la Azohía (Mazarrón) and the Villas Caravan site near La Manga. People trapped in their vehicles had to be rescued, some by helicopter or tractor. Hundreds of people were trapped in their homes without being able to leave. According to Civil Protection data, more than 2000 people were evacuated and more than 1000 rescues were carried out, of which a hundred were by air.

10.- Harmful effects on the population. Fortunately, in the Region of Murcia, there were no fatal casualties, but the economic damage was extensive. Thousands of people were affected, especially in Los Alcázares. Taking advantage of the situation, homes, shops and the post office of Los Alcázares were raided or damaged. Water and electricity were cut off in many places.

11.- Damage to property. Some of the newspaper headlines speak for themselves: 15 boats moored in the Algameca of Cartagena were lost in the Mediterranean; 25 rubbish containers were hauled out of the Mar Menor (4200 t of waste); in Los Alcázares 14,000 homes, along with infrastructure and companies, were affected by the DANA, and 400 vehicles were damaged; Cartagena city council took away 180 tonnes of household items in Los Nietos and Los Urrutias (south of the Mar Menor). Other headlines such as "We've lost everything that was in the house" and "Mud up to the eyeballs" reflect people's experiences.

12.- Damage to infrastructure. Damage to infrastructure was widespread and we only mention: damage to the railway lines linking Murcia with Alicante, Albacete, Cartagena and Lorca, and also $100 \mathrm{~m}$ of the new high-velocity track being built; the infrastructure carrying the water of the Tagus-Segura transfer channel system fractured; dozens of roads throughout the region were damaged, and traffic was prohibited; rupture of a dam and mining depot in Portman; damage to a desalination plant and a water treatment plant; destruction of promenades; the Tomás Maestre pleasure harbour in La Manga was affected by the rising sea level; destruction of the Murcia-Rio garden project in the city of Murcia; fallen masonry in the Santa Florentina market in Cartagena; a sinkhole appeared in Juan de Borbón Avenue in Murcia; and damage to countless irrigation infrastructures.

13.- Damage to agriculture, livestock and fisheries. Losses in agriculture and collateral damage featured regularly in the information provided and related declarations by representatives of agricultural associations, farmers and even by the Minister of Agriculture, who described vegetables, grapes, rice and citrus fruits as being among the most affected crops; and some farmers from Jumilla said that the harvest had been seriously threatened and that vineyards, olive trees and almond trees could not be recovered, and that 150,000 hectares were affected by the rupture of the hydraulic infrastructure. Job 
losses in the countryside were mentioned, as was the intention to provide a temporary subsidy for daylabourers who were out of work. Farmers advocated that the European Commission activate the Solidarity Fund to deal with damage in the production sector. Regarding livestock, 1500 animals were estimated to have died only in the Campo de Cartagena. The storm led to tuna escaping from a fish farm, with 1300 dead tuna washing up on the beaches of La Manga and south of Alicante. Days after the DANA, dead fish and seahorses appeared in the Mar Menor and a month later (October 13th) thousands of fish and crustaceans were seen to have died in the northern sector of the Mar Menor. ANSE, a nature protection association and the fishermen of San Pedro del Pinatar (the municipality most affected) proposed a one-year paid ban on fishing.

14.- Damage to industry and the services sector. The greatest damage was to the tourist sector, with the cancellation of reservations in hotels and apartments in the Mar Menor, the non-arrival of tourists from cruise ships scheduled to call in Cartagena or the closing for several weeks of golf courses in the Campo de Cartagena-Mar Menor area. The significant losses to the Region's cultural heritage sites should also be mentioned.

15.- Effects on the Mar Menor lagoon. News on the Mar Menor was abundant during the days that the DANA occurred and continued until the end of October because of the lagoon's poor environmental state after the episode. However, only items related to the DANA itself have been collected here. Most reports mentioned the sediments that entered the lagoon, turning it brown. The Sentinel satellite image of September 13th, 2019 (Fig. 6) is very eloquent in this respect. According to a scientific report published in La Verdad on November 14, 2019, the sediments that entered the lagoon in the DANA episode were estimated at 100,000 tonnes, which contained between 500 and $1000 \mathrm{t}$ of nitrates, more than $100 \mathrm{t}$ of phosphates and $35 \mathrm{t}$ of ammonium. In addition, the inflow of fresh water, according to some experts, would cause a decrease in salinity with unpredictable effects on flora and fauna. Both factors (sediments and fresh water) would have contributed to the massive death of fish and crustaceans that occurred days later. The DANA aggravated the poor health of the Mar Menor and numerous news articles were dedicated to this, and especially to the individuals and organisation that, to this day, to propose actions for its improvement. The mass demonstrations that took place in Murcia and Cartagena in defence of the Mar Menor, which were also echoed by the press, should be mentioned.

16.- Solidarity and aid provided to those affected. People's solidarity was evident from the day of the episode up until the end of October. Thousands of volunteers who, either on buses that were chartered for free or by their own means, travelled to Los Alcázares, Torre Pacheco, San Javier, Los Nietos or Molina de Segura, to assist in the cleaning of houses, schools, churches and streets. Banks made donations and opened accounts to help in this process, provided free loans before official aid and compensation were provided, and established special credit lines for farmers and families, as well as zero-cost lending to small businesses and the self-employed. Local folklore groups, "Peñas Huertanas", offered to cook for the victims; Jesús Abandonado (a charitable organisation, provided food and accommodation; the University of Murcia organised a collection to provide essential; the inhabitants of nearby Alcantarilla collected $8 \mathrm{t}$ of food, blankets and clothes; there were campaigns to collect school material and textbooks; numerous private individuals and companies in Los Alcázares gave furniture and other items; another charity, Caritas, offered a variety of goods and services, including a truckload of furniture; concerts, music galas and meals, while sporting events were organized for the benefit of the affected; the Los Alcázares City Council reduced property taxes (IBI) and lowered the cost construction permits. Cartagena paid the water bills to those affected by the DANA. Hundreds of animals were also rescued from the waters by volunteers and animal protection associations. 


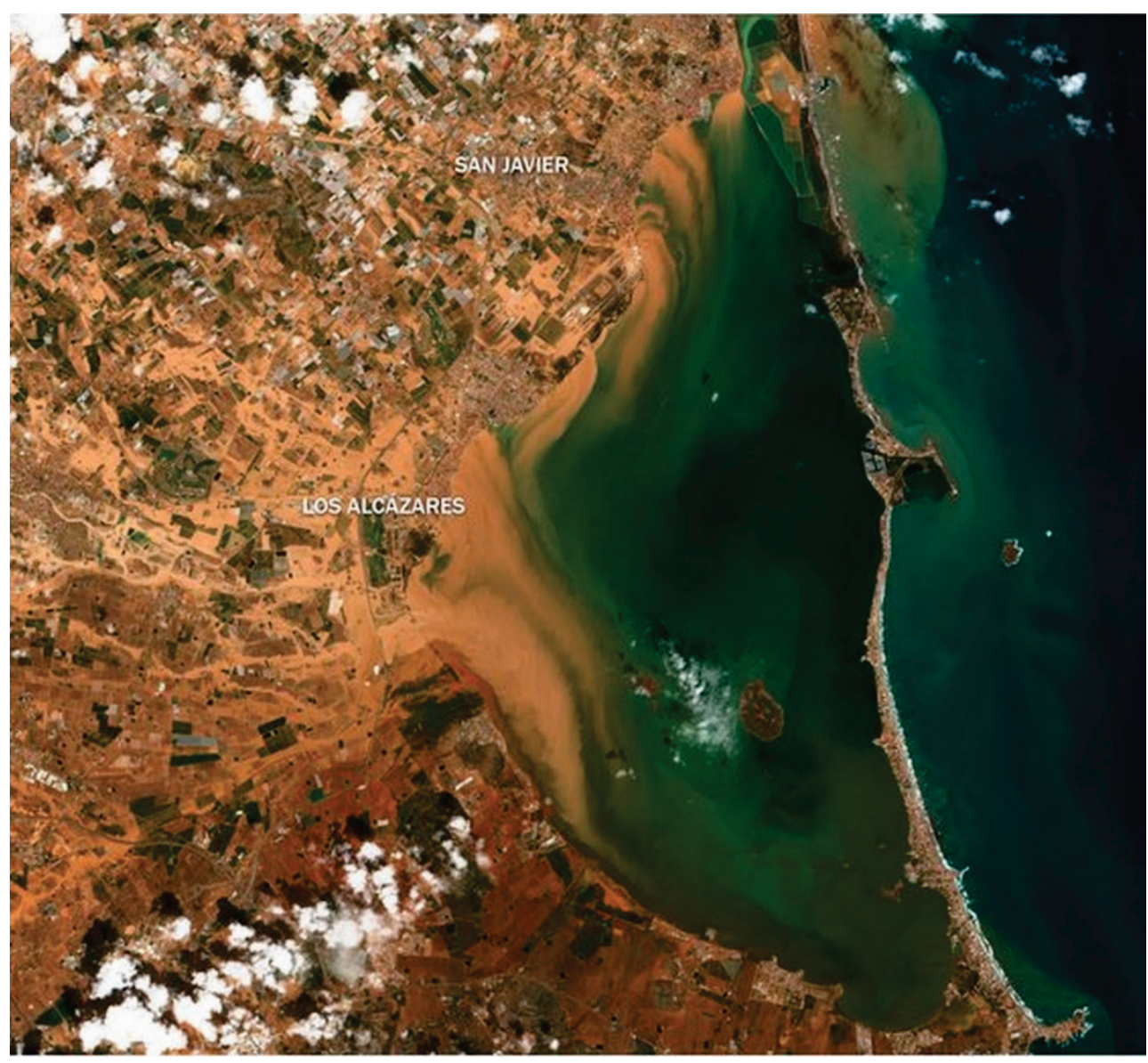

Figure 6. Image of the Mar Menor on 13th of September 2019. Note the sediments entering the Mar Menor and the flooded towns and villages. Source: Sentinel. 2.

17.- Emergency management. In addition to personnel from state agencies (CHS, AEMET, UME), staff from regional agencies and companies, the Red Cross, public health official, local police, municipal civil protection services, firefighters and forest protection brigades also participated in emergency relief. Level 2 of the Special Emergency Civil Protection Plan was activated on 12th September, and was lowered to level 1on the 19th before being deactivated on October 4th. Municipal Emergency Plans had to be activated in Águilas, Lorca, Los Alcázares, Mazarrón, Molina de Segura, Murcia, Puerto Lumbreras, San Javier and San Pedro del Pinatar. According to regional government sources, the September DANA triggered 8572 calls to the emergency phone number (112) (one every 10 seconds), of which 1965 were requests for information; 1697 were about floodwater in basements and lower floors, 492 about removing obstacles blocking public roads and 460 requesting rescue from trapped vehicles or their homes (60 of which involved air rescues. The municipality with the most incidents treated was Murcia city (1336), followed by Los Alcázares (1073), Cartagena (467) and San Javier (464). The Defence Ministry deployed almost 900 military personnel and a hundred vehicles in the province.

18.- Damage and loss assessment. Two days after the DANA, estimates of the damage begun to be made and, in Los Alcázares alone, losses amounted to more than 100 million euros. Almost every day new figures appeared in the press, but until October there was no realistic evaluation of the damage. The Insurance Compensation Consortium considered 12,000 homes, 5000 vehicles and 113,300 hectares of crops had been affected by flooding. Losses in agriculture led to some 1720 declarations of damage as a result of landslides, gullies, cracked roads, broken fences, and damaged factories or greenhouses. The losses in the agricultural sector amounted to 125 million euros, which includes damage to production infrastructures (52.4 million euros), losses in crop production (23.3 million euros), livestock and farmed 
fish (25.0 million euros), damage to rural roads and municipally owned facilities (18.5 million euros) and public infrastructure related with the environment and water purification (5.6 million euros). In addition, private assets were calculated at 238 million euros, municipal facilities 145 million euros, state infrastructure 60 million euros and those of province-owned at 46.5 million euros. The overall damage assessment was 590 million euros. Los Alcázares suffered by far the most damage compared with the rest of the affected municipalities, followed by San Pedro del Pinatar, Torre Pacheco and the city of Murcia.

19.- Declaration of a disaster area. The request that the affected municipalities be declared a catastrophic zone was unanimous. The voices that requested the same were all the political parties, the president of the autonomous community, the regional assembly and the town councils of Los Alcázares, San Javier, San Pedro del Pinar, Abarán, Beniel, Lorquí, Mazarrón, Torre Pacheco, Cartagena and Jumilla. In addition, the regional government demanded that the Spanish state ask for the European contingency fund be applied to help cover the losses.

20.- Responsibilities. The harsh criticism and the demand for responsibility, especially from public and political organisms, was a recurring theme in the press. In particular, the responsibility of the CHS was questioned for not keeping the river beds clear of reeds, for not cleaning the channels, for not preventing the elimination of the dense mesh of tributaries, ramblas and brooks, and for not delimiting the rambla of Abanilla; the residents of Alquerías protested about the train tracks being built in the bed of the Tabala rambla; Los Alcázares threatened to take the ministry responsible to court and denounced the company that built the AP7 motorway of not adequately channelling the rambla de La Maraña, which was one of the main causes of the flooding in this municipality; elected leaders were criticised for not doing their jobs properly and asked to legislate on limitations of use, to carry out urban planning properly, to make specific plans to deal with flooding (as required by regional and national laws), or to solve once and for all the problem of health- hazardous mining waste that, after the rains, reached the southern shores of the Mar Menor, through the ramblas of Las Matildes, Beal and Carrasquilla.

21.- Compensation and payments. From the outset, the Insurance Compensation Consortium kept policy holders informed, and the councils helped process the aid. There were almost 14,000 applications for compensation (mostly for damage to homes) and, as of October 14, the Consortium had already paid 1.76 million euros in compensation. The President of the Autonomous Community said he was disappointed with the government aid of 749 million euros to be distributed among 20 provinces, which only covered $50 \%$ of the damage.

22.- Visits by politicians, personalities, and their statements. There were many articles related with visits to the affected areas by public officials and different personalities, as well as statements by political leaders in which there was no shortage of criticism and cross-accusations between the different parties. Politicians who visited the affected areas were the Spanish Prime Minister of the nation, the regional president and several advisers, leaders of other regional and national parties, the minister of defence, the Bishop of Cartagena and the King and Queen of Spain.

23.- Repairs and cleaning. The repairs and cleaning were arduous, reflecting the damage. In addition to cleaning houses, streets and roads, water had to be pumped from in houses, garages, and even fields to prevent crops from rotting. Despite the effort, several weeks after the DANA many areas remained flooded with mosquito infestations and complaints from inhabitants. In early October, the CHS repaired 
the Tagus-Segura Water Transfer system, and in late October the Autonomous Community began to repair damage to regional roads, beaches and promenades.

24.- Causes of flooding. The focus was of complaint was the building that had taken place in areas at risk of flooding, exposing property, people and animals to danger. Speculation, bad organisation, neglect and corruption on the part of local officials were blamed for the development that had been allowed, especially along the coast. The mayor of Los Alcázares believes that the construction of the airport, the new developments and the transformation of flood channels had contributed to the damage caused. An opinion piece mentioned the relationship between the anthropogenic sealing of the soil and the floods, stating that $40 \%$ of the municipality of the municipal area was sealed. A report by the Sustainability Observatory (OSE, 2019) indicated that tourism-driven urbanistic pressure had increased the risk. Another cause mentioned was climate change which favours the generation of DANAS and heavy rainfall, even though this was not the main cause of flooding in the case in hand.

25.- Solutions and measures. All political parties agreed that we must learn from The DANA and undertake work to prevent new floods. The inhabitants of Los Alcázares in particular (because of the floods that they have already suffered in recent years), are calling for definitive solutions. Asa result, government agencies, scientists and others have made proposals for action that the newspapers have described. Because of the criticisms that the local Government has received, one of its measures has been the creation of a Committee of Experts to seek solutions and prevent floods. The CHS has prepared a study to determine actions in the Albujón and La Maraña ramblas, including diverting the La Maraña rambla into the Albujón and channelling the Albujón rambla, the recovery of the channels of ramblas and small ramblas in the Mar Menor basin (even if expropriation is necessary) and to promote the project that will reroute the Viznaga rambla to prevent flooding in the villages near Lorca (Campillo and Torrecilla). It is also proposed to expand the floodplains and the margins of the ramblas and to construct new hydraulic infrastructures; one engineer has suggested constructing a $30 \mathrm{~km}$ canal in the Campo del Mar Menor parallel to the AP-7 motorway and the dual carriageway towards La Manga, completing it with several reservoirs for water collection. Environmental organisations such as ANSE, who are against new infrastructure, are committed to reducing intensive agriculture and urban projects, and suggest eliminating some of the existing structures. Geographers, for their part, call for an urgent change in urban policies and correct urban planning.

26.- Other. Although the news has been grouped into a large number of topics, some items are still difficult to classify, such as the widely repeated story that the former emergency director went to the theatre during the emergency; reports of illegal dumping into the rivers, taking advantage of the flood; references to previous floods such as that of Santa Teresa, San Miguel or San Fulgencio, prayers to the Vera Cruz (True Cross) for the victims, etc.

Jokes. There was no lack of humorous passages, particularly in La Verdad. For example, the cartoon of people on a roof waiting to be rescued, the model of an oversized sardine that sits in the middle of the Segura River in the city of Murcia appearing in La Manga, the emblematic angel of the sculptor Salzillo under water or fish trying out of the water to breathe.

\section{Discussion}

It is worth mentioning how flooding is part of the natural dynamics of rivers, especially Mediterranean ones and are indispensable for maintaining their ecological condition. Flooding has countless benefits for society as a whole, such as the natural fertilisation of farmland, the replenishing of alluvial aquifers, the dilution of pollutants, increasing biodiversity, supplying sediments and nutrients 
to the deltas (Conde, 2013), or pushing back salt water. However, despite the construction of more hydraulic infrastructure works, the risk levels remain stable and may even increase, as vulnerability increases (Vallejo, 2000). In the Segura basin, where flooding is frequent (Romero Díaz, 2007), numerous reservoirs and channels have been built to regulate its network; however, the risk of flooding still remains, as seen from the effects of the DANA discussed herein, especially from the Segura river. In other places, such as the coastal municipality of Los Alcázares, the degree of exposure is high since it occupies the mouth of one rambla (La Maraña) and it is close to another (El Albujón). The space drained by both has been transformed by intensive irrigation and misplaced urban planning, so that in the face of high-intensity rainfall, the number of floods in recent years has continued to grow.

However, the DANA of September 2019 (called the Santa Maria Flood), is characterised as exceptional for the following reasons: (i) it produced one of the most devastating and catastrophic floods that to have taken place in Spain in recent years; (ii) torrential rainfall in excess of $300 \mathrm{~mm} / \mathrm{day}$ was recorded in several places; (iii) it lasted five days as it moved south and then returned north, causing some areas to suffer its effects twice; (iv) the extent and violent nature of the floods, since the rivers and ramblas overflowed, flooding streets, fields and towns, and cutting off many communication routes (roads, railways and airports), and forcing schools and universities to close; (v) or the number of evacuees and the many emergency personnel deployed.

\subsection{How the news developed}

From the analysis of the news we have made, the logical sequence of a natural catastrophe, as identified by Quarantelli and Dynes (1977), is evident. According to these authors, the disaster cycle includes different stages, which can be summarised into: prevention, mitigation and preparation. The last of these consists of designing a series of activities that, properly implemented, will allow authorities to prepare before the impact and provide a quick response during the disaster. Once the disaster has occurred, response activities begin, including search and rescue, relief and assisting people. In the case at hand, the DANA lasted three days. Finally, there remains rehabilitation and reconstruction.

Although it is difficult to identify the beginning and end of each of these phases, in the case under study they could be specified as shown in Table 3.

Table 3. Sequence of the disaster, publication days and main topics.

\begin{tabular}{|l|l|l|}
\hline Sequence of the disaster & Date of publication & Main topics \\
\hline $\begin{array}{l}\text { Prevention, mitigation } \\
\text { and preparation }\end{array}$ & $\begin{array}{l}\text { From the 10th to the 13th of } \\
\text { September }\end{array}$ & $\begin{array}{l}\text { 1. Alert and prevention } \\
\text { 2. Suppression of activities }\end{array}$ \\
\hline $\begin{array}{l}\text { Rescue, relief and } \\
\text { assistance to people }\end{array}$ & $\begin{array}{l}\text { From the 13th to the 15th of } \\
\text { September }\end{array}$ & $\begin{array}{l}\text { 4. Climatological and weather aspects } \\
\text { 5. Hydrological aspects } \\
\text { 6. State of riverbeds, banks and } \\
\text { beaches } \\
\text { 7. Flooded areas and places } \\
\text { 9. Evacuations, rescues and } \\
\text { displacements } \\
\text { 10. Effects on the population } \\
\text { 12. Damage to infrastructure } \\
\end{array}$ \\
& $\begin{array}{l}\text { 13. Damage to agriculture and } \\
\text { livestock } \\
\text { 17. Emergency management }\end{array}$ \\
\end{tabular}




\begin{tabular}{|c|c|c|}
\hline \multirow[t]{3}{*}{$\begin{array}{l}\text { Response, rehabilitation } \\
\text { and reconstruction. }\end{array}$} & After the 15th of September & $\begin{array}{l}\text { 3. Resumption of activities } \\
\text { 8. Management of reservoirs } \\
\text { 11. Damage to property } \\
\text { 16. Solidarity with and aid to those } \\
\text { affected } \\
\text { 19. Declaration of a disaster area } \\
\text { 22. Visits by politicians and } \\
\text { personalities }\end{array}$ \\
\hline & After the 17th of September & $\begin{array}{l}\text { 14. Damage to industry and other } \\
\text { property } \\
\text { 18. Damage and loss assessment } \\
\text { 21. Compensation and payments } \\
\text { 23. Repairs and cleaning }\end{array}$ \\
\hline & $\begin{array}{l}\text { From the } 15 \text { th of September to } \\
\text { the } 31 \text { st of October }\end{array}$ & $\begin{array}{l}\text { 15. Effects on the Mar Menor lagoon } \\
\text { 20. Responsibilities } \\
\text { 24. Causes of flooding } \\
\text { 25. Solutions and measures } \\
\text { 26. Other }\end{array}$ \\
\hline
\end{tabular}

\subsection{Differences between the two newspapers}

The 435 news articles published by La Verdad and the 333 articles of La Opinión were compared to identify those that were analogous in content and the message they conveyed. Of all these, only 45 news can be classified as being the same (Table 4), with very similar contents and published on the same days, which indicates that each newspaper, with the same information obtained from different sources or reporters, treated the news with its own media centric bias (Valera Ordaz, 2016). Both newspapers focused on characterising this DANA as an exceptional weather phenomenon and proposed a climate-related emergency be declared. Priority issues in both newspapers were the rescues, evacuations and solidarity for those affected, the effects on the Mar Menor and visits by politicians and personalities.

Although the vast bulk of the news was negative and dealt with the catastrophic consequences of the floods, some positive considerations were reported such as the beneficial effects of rain in the Campo de Cartagena (which would save water for irrigation), or the increased levels of reservoirs. On the 5th of October, La Verdad mentioned the $20 \mathrm{Hm}^{3}$ of water accumulated at the Santomera reservoir, and on the 27th of October that the reservoirs of the basin had increased by $18 \%$.

We have not found any significant differences in the rigour of the news published in the newspapers analysed, although we have counted a greater number of scientific and opinion articles published in La Verdad than in La Opinión. 
Table 4. Similar news published in the two newspapers.

\begin{tabular}{|c|c|c|}
\hline Subject & Date & News which was the same in both newspapers \\
\hline 1 & 12 Sept. & Cleaning of ramblas \\
\hline 2 & 12 Sept. & Suspension of school classes \\
\hline 2 & 15 Sept. & Cruise ships that decide not to dock in Cartagena \\
\hline 2 & 15 Sept. & Train transport remains interrupted \\
\hline 2 & 20 Sept. & There is still no drinking water in Los Alcázares \\
\hline 3 & 15 Sept. & Classes in schools resume tomorrow \\
\hline 3 & 20 Sept. & The railway line with Albacete has been restored \\
\hline 3 & 21 Sept. & Roads are reopened, but some are still closed \\
\hline 3 & 16 Oct. & The railway line with Cartagena is restored \\
\hline 4 & 13 Sept. & Rain distribution map in the Region \\
\hline 4 & 20 Sept. & Exceptional weather phenomenon \\
\hline 4 & 24 Sept. & The Environment Ministry calls for "Climate Emergency" \\
\hline 5 & 14 Sept. & The Segura about to overflow in the city of Murcia \\
\hline 6 & 13 Sept. & Fear in Santomera and Beniel over possible flooding from the river \\
\hline 6 & 15 Sept. & Fear in the city of Murcia because of the rising water level \\
\hline 7 & 15 Sept. & River overflows in El Raal \\
\hline 7 & 16 Sept. & Floods in villages near Lorca \\
\hline 8 & 14 Sept. & The gates of Santomera reservoir opened \\
\hline 8 & 16 Sept. & Santomera reservoir manages to retain $19 \mathrm{Hm}^{3}$ \\
\hline 9 & 13 Sept. & Rescues and flooded streets in Molina de Segura \\
\hline 9 & 13 Sept. & Many residents are evacuated from El Raal, Alquerías, Zeneta and Santa Cruz \\
\hline 9 & 17 Sept. & Numerous families in El Raal still cannot return to their homes \\
\hline 10 & 14 Sept. & Thousands of victims in the Region \\
\hline 12 & 13 Sept. & The Tagus-Segura transfer channel overflows and suffers a serious breakage \\
\hline 13 & 16 Sept. & Storm dumps hundreds of dead tuna in La Manga \\
\hline 15 & 17 Sept. & It is estimated that $15-20$ days must pass for water to stop entering the Mar Menor \\
\hline 15 & 29 Sept. & $\begin{array}{l}\text { Beaches in the southern parts of the Mar Menor are closed to the public because of } \\
\text { the presence of a bacterium }\end{array}$ \\
\hline 15 & 13 Oct. & Heavy fish mortality in San Pedro del Pinatar \\
\hline 15 & 18 Oct. & Mass demonstration in Cartagena. Demand for solutions \\
\hline 16 & 16 Sept. & Wave of solidarity in Los Alcázares \\
\hline 16 & 17 Sept. & The wave of solidarity grows in Los Alcázares and other locations \\
\hline 16 & 17 Sept. & Buses are chartered to help those affected \\
\hline 17 & 14 Sept. & Defence Ministry deploys military personnel to affected areas \\
\hline 18 & 17 Sept. & Estimates of damage reach hundreds of millions \\
\hline 18 & 4 Oct. & Damage figures are given for all affected sectors \\
\hline 19 & 14 Sept. & Demands for declaration of catastrophic zone \\
\hline 19 & 20 Sept. & Mazarrón and Jumilla support catastrophic zone declaration \\
\hline 20 & 20 Sept. & $\begin{array}{l}\text { Neighbours of Alquerías protest to Adif over the layout for the new high-speed train } \\
\text { (AVE) tracks }\end{array}$ \\
\hline 22 & 14 Sept. & The Prime Minister visits the affected areas \\
\hline 22 & 17 Sept. & The Bishop of Cartagena visits the affected areas \\
\hline 22 & 24 Sept. & The Minister of Defence visits the affected areas \\
\hline 22 & 27 Sept. & The leader of the PP visits the affected areas \\
\hline 22 & 5 Oct. & The King and Queen visit the affected areas \\
\hline 23 & 8 Oct. & Mosquito plague because of stagnant waters \\
\hline 26 & 15 Sept. & The emergency general director went to the theatre in the middle of the crisis \\
\hline
\end{tabular}

\section{Conclusions}

Although it would be necessary to contrast its effectiveness, the proposed database allows information from the newspaper archives to be organised into indicators that give insight into the importance of different aspects of an episode. The sequence mentioned by Quarantelli and Dynes (1977) and the way it permits classification of the news allow the importance of each of the stages of a disaster to be evaluated independently and a comparison with other flood episodes to be made through a 
quantitative or qualitative contrast of each of the topics considered important. This could point to new findings, such as the importance of preparation and planning from the time one episode occurs until another appears; the perseverance and intensity of the impact and its effects on the population and the organisational systems involved and the most effective risk management strategies, etc. There are studies that involve similar approaches to gauge the importance of an event in terms of intensity of loss and magnitude of danger (Camarasa-Belmonte and López, 2016), however, there are not so many regarding the importance of such episodes as it passes through each of its phases as is proposed here.

In relation to the results of this specific case study, the tasks related with prevention and warning prior to the materialisation of the risk were relevant and consistent with what subsequently happened, to the extent of stopping school activity and, partially halting work in general for 48 hours. This was the correct procedure according to the CHS because the DANA was as one of the most devastating and catastrophic to have occurred in Spain in recent years, and the rainfall recorded could be classified as extraordinary. The rains were persistent and concentrated, causing rivers and ramblas to burst their banks, flooding streets, fields and urban centres. In the Vega Alta, from Cieza to its mouth, the Segura River overflowed in numerous places, and the area around the Mar Menor was also badly hit.

With regard to the impact of the emergency and the subsequent relief phase, the effects were multiple, the most emphasised by the press being those related with agriculture, livestock, fisheries, aquaculture, transport, tourism, marine ecosystems, on the coast, infrastructure of all kinds or personal property. Some data, measured or estimated, reveal the magnitude: $3351 / \mathrm{m}^{2}$ of rain fell in Molina de Segura and $2641 / \mathrm{m}^{2}$ in Torre Pacheco; the total volume of water in the Segura basin was $2800 \mathrm{hm}^{3}$ (more than twice the capacity of all the reservoirs); $51 \mathrm{hm}^{3}$ of water poured into the sea through the Segura river; 100,000 $t$ of sediments entered the Mar Menor (with a content of between 500 and $1000 \mathrm{t}$ of nitrates and $100 \mathrm{t}$ of phosphates). Damage was estimated at 590 million euros and there were 14,000 claims for compensation.

Finally, the period of rehabilitation and reconstruction lasted a month and a half in terms of its importance in the press. However, according to the disaster cycle, the boundaries between the last event and the beginning of prevention, mitigation and preparation plans would overlap. What is interesting in the case that we have dealt with here is how important preventative actions are now regarded compared with response actions. It is also encouraging that the inhabitants concerned are calling for new planning measures or strategies to be drawn up, rather than accepting the large financial outlay in the form of public works proposed by the regional government.

From the analysis carried out, we cannot conclude that the news appearing in the press has directly motivated a response from the administration, but we certainly consider that these may have had quite an influence. One year after the DANA episode, the panel of experts, which was set up immediately after the event, has finally proposed a series of measures, in which the Community of Murcia will invest 77 million euros until 2023, with the aim of minimising the impact of the floods. These measures include actions related to the planning and improvement of the territory, the construction of rainwater collectors, flooding ponds and the implementation of the region's flood prevention plan (POTPRI).

\section{Acknowledgements}

This paper was partly funded by project 20912/PI/18, financed by "Fundación Séneca-Agencia de Ciencia y Tecnología de la Región de Murcia (Spain)”. 


\section{References}

Archer, D.R., Fowler, H.J. 2018. Characterising flash flood response to intense rainfall and impacts using historical information and gauged data in Britain. $J$ Flood Risk Management 11, S121-S133. https://doi.org/10.1111/jfr3.12187

Archer, D., O'Donnell, G., Lamb, R., Warren, S., Fowler, H.J. 2019. Historical flash floods in England: New regional chronologies and database. Journal of Flood Risk Management, 12 (S1), art. no. e12526. https://doi.org/10.1111/jfr3.12526

Barriendos, M., Gil-Guirado, S., Pino, D., Tuset, J., Pérez-Morales, A., Alberola, A., Costa, J., Balasch, J.C. Castelltort, X., Mazón, J., Ruiz-Bellet, J.L. 2019. Climatic and social factors behind the Spanish Mediterranean flood event chronologies from documentary sources (14th-20th centuries). Global and Planetary Change 182, 102997. https://doi.org/10.1016/j.gloplacha.2019.102997

Calvo García-Tornel, F., Conesa García, C., Álvarez Rogél, Y. 2001. La inundación de octubre de 1879 en el bajo Segura. Magnitud y efectos inducidos. Estudios Geográficos 242, 7-27. http://doi.org/10.3989/egeogr.2001.i242.292

Camarasa-Belmonte, A. M., López, M. P. 2016. Lluvias in situ en la comunidad valenciana. Relación entre indicadores pluviométricos, llamadas al centro de coordinación de emergencias (112) y relación de daños, durante el episodio de 26-30 de noviembre de 2016. En: El clima: aire, agua, tierra y fuego. Publicaciones de la Asociación Española de Climatología (AEC) Serie A 11, 233-244.

Conde, O. 2013. Las crecidas también aportan múltiples beneficios. Fundación Nueva Cultura del Agua. Zaragoza

Cuello Gijón, A. 2010. El discurso fluvial social. Una aproximación desde el análisis de prensa en un episodio de inundaciones en la provincia de Cádiz. Trabajo Fin de Master de Gestión Fluvial Sostenible y Gestión Integrada de Aguas. Universidad de Zaragoza.

Cuello Gijón, A. 2018. Las Inundaciones del invierno 2009-2010 en la prensa, un recurso educativo para las ciencias sociales. REIDICS 2, 70-87. https://doi.org/10.17398/2531-0968.02.70

Domínguez-Castro, F., Ramos, A.M., García-Herrera, R., Trigo, R.M. 2015. Iberian extreme precipitation 1855/1856: an analysis from early instrumental observations and documentary sources. International Journal of Climatology 35, 142-153. https://doi.org/10.1002/joc.3973

Ezcurra, J. (2007). El Plan de Defensa contra Avenidas de 1987 en la cuenca del Segura. Plan de defensa de 1987 frente a avenidas en la cuenca del Segura. XX Aniversario, 13-33.

García Martínez, E., Marti Ezpeleta, A. 2000. Riesgos climáticos en Galicia: una aproximación a través de la prensa (1983-1997). Eria 53, 259-269.

Gil-Guirado, S., Pérez-Morales, A., López-Martínez, F. 2019. SMC-Floods database: high resolution press database on floods for the Spanish Mediterranean Coast (1960-2015). Nat. Hazards Earth Syst. Sci. Discuss., https://doi.org/10.5194/nhess-2019-10

Gutiérrez Abril, V. 2016. Episodios de inundaciones en España 1995-2014. Trabajo Fin de Master en Análisis y Gestión de Emergencias y Desastres. Universidad de Oviedo. Oviedo (Spain).

Hernández Varela, L., Lozano Valencia, M. A., Soleto García, C. 2003. Estudio de los acontecimientos meteorológicos extraordinarios en la Comunidad Autónoma del País Vasco (1870-1954) a través de la prensa. Investigaciones Geográficas 30, 165-180. http://dx.doi.org/10.14198/INGEO2003.30.03

Lang, M., Coeur, D., Audouard, A., Villanova-Oliver, M., Pène, J.P. 2016. BDHI: a French national database on historical floods. E3S Web of Conferences, 04010. https://doi.org/10.1051/e3sconf/20160704010

León González-Mazón, P. 2017. Inundaciones en Sevilla a través de las fuentes periodísticas (siglo XX). Trabajo Fin de Grado en Geografía y Gestión del Territorio e Historia. 60 pp., Universidad de Sevilla, Sevilla (Spain).

Llasat, M. C., Llasat-Botija, M., Barnolas, M., López, L., Altava-Ortiz, V. 2009. An analysis of the evolution of hydrometeorological extremes in newspapers: the case of Catalonia, 1982-2006. Nat. Hazards Earth Syst. Sci. 9, 1201-1212. http://doi.org/10.5194/nhess-9-1201-2009

Llasat-Botija, M., Llasat, M. C., López, L. 2007. Natural Hazards and the press in the western Mediterranean region. Adv. Geosci.,12, 81-85. http://doi.org/10.5194/adgeo-12-81-2007 
Llasat-Botija, M., López, L., Llasat, M.C. 2006. Percepción social de los riesgos naturales en Cataluña a partir de la información de prensa. Clima, sociedad y medio ambiente. Publicaciones de la Asociación Española de Climatología (AEC), Serie A, 5, 777-786.

Lopera Pareja, E. H. 2017. ¿Esto es por el cambio climático? Los fenómenos meteorológicos extremos en la prensa española (2000-2010): ocurrencia y atención mediática. Anuario Electrónico de Estudios en Comunicación Social "Disertaciones" 10 (2), 79-103. https://doi.org/10.12804/revistas.urosario.edu.co/disertaciones/a.4630.

Mayer Suarez, P. 1999. Un siglo de temporales en la prensa de Gran Canaria. Vegueta 4, 267-282.

Mayer Suárez, P. 2002. Desarrollo urbano e inundaciones en la ciudad de las Palmas de Gran Canaria (1869-2000). Investigaciones Geográficas 28, 145-159. http://doi.org/10.14198/INGEO2002.28.07

Melinda, L. 2015. Early historical floods in Central Texas. World Environmental and Water Resources Congress: floods, droughts, and ecosystems. Austin, pp. 48-53.

Olcina Cantos, J. 2005. La prensa como fuente para el estudio de los tiempos y climas. Revista de Historia Moderna 23, 185-232. http://doi.org/10.14198/RHM2005.23.07

Olcina Cantos, J., Pérez García-Torres, A.P., Poveda Martínez, R.M. 2004. La prensa como fuente para el estudio de los episodios de inundación. En A. Gil Olcina, J. Olcina Cantos y A.M. Rico Amorós (Eds.) Aguaceros, aguaduchos e inundaciones en áreas urbanas alicantinas. Publicaciones de la Universidad de Alicante, pp. 37-84, Alicante (Spain).

Ortuño Cano, M., Gentili, J., Moretto, B. 2019. Eventos de exceso hídrico en la prensa escrita (sistema de Ventania, Argentina). Boletín Geográfico 41, 53-75.

OSE (2019). Informe 50 municipios más construidos en el litoral español. Riesgo de inundación es en la primera franja de costa. https://www.observatoriosostenibilidad.com/2020/09/27/donde-sera-el-proximotemporal-gloria/

Pejenaute Goñi, J. 2008. Inundaciones históricas en los valles cantábricos navarros (1881-2007). Publicaciones de la Asociación Española de Climatología, Serie A, 6, 209-221.

Pérez Morales, A., Gil Guirado, S. 2012. La avenida de 22 de octubre de 1948 en la cuenca del Segura. Revisión y análisis. Estudios Geográficos 272, 163-187. https://doi.org/10.3989/estgeogr.201206

Prohaska, S.,Pekarova, P., Ilic, A. 2019. Historical floods along the Danube River from 1012 to the present. HRVATSKE VODE 27 (108), 119-128.

Quarantelli, E. L., Dynes, R. R. 1977. Response to social crisis and disaster. Annual review of Sociology 3(1), 2349. http://doi.org/10.1146/annurev.so.03.080177.000323

Rashid, H. 2011. Interpreting flood disasters and flood hazard perceptions from newspaper discourse: Tale of two floods in the Red River valley, Manitoba, Canada. Applied Geography 31, 35-45. http://doi.org/10.1016/j.apgeog.2010.03.010

Romero Díaz, A. 2007. Las inundaciones. En A. Romero Díaz (Coord.) Atlas Global de la Región de Murcia. La Verdad CMM S.A. Murcia, pp. 250-259.

Torrens Calleja, J.M., Rosselló Geli, J., Grimalt Gelabert, M. 2016. Recopilación de información vinculada a temporales de viento, precipitaciones torrenciales e inundaciones en la ciudad de Palma de Mallorca entre los años 2000 y 2015. X Congreso Internacional AEC: Clima, sociedad, riesgos y ordenación del territorio. http://doi.org/10.14198/XCongresoAECAlicante2016-39

Valera Ordaz, L. V. 2016. El sesgo mediocéntrico del framing en España: una revisión crítica de la aplicación de la teoría del encuadre en los estudios de comunicación. ZER Revista de Estudios de Comunicación 21 (41), 13-31. http://doi.org/10.1387/zer.17259

Vallejo, I. 2000. Las Inundaciones en la cuenca del Guadalquivir. Serie Geográfica 9, 133-149. Universidad de Sevilla. 